\title{
The Perception of Polish Business Stakeholders of the Local Economic Impact of Maritime Spatial Planning Promoting the Development of Offshore Wind Energy
}

\author{
Tomasz Laskowicz (D)
}

check for updates

Citation: Laskowicz, T. The Perception of Polish Business Stakeholders of the Local Economic Impact of Maritime Spatial Planning Promoting the Development of Offshore Wind Energy. Sustainability 2021, 13, 6755. https://doi.org/ $10.3390 /$ su13126755

Academic Editors: Eduardo José Rocha Medeiros and Jacek Zaucha

Received: 27 May 2021

Accepted: 10 June 2021

Published: 15 June 2021

Publisher's Note: MDPI stays neutral with regard to jurisdictional claims in published maps and institutional affiliations.

Copyright: (C) 2021 by the author. Licensee MDPI, Basel, Switzerland. This article is an open access article distributed under the terms and conditions of the Creative Commons Attribution (CC BY) license (https:/ / creativecommons.org/licenses/by/ $4.0 /)$.
Faculty of Economics, University of Gdańsk, 81-824 Sopot, Poland; tomasz.laskowicz@phdstud.ug.edu.pl

\begin{abstract}
The recently adopted maritime spatial plan for Polish sea waters promotes offshore wind farm (OWF) development. The study's identification of the local municipalities affected by offshore development was based on the plan's provisions. Through the analysis of the plan and literature findings, both positive and negative impacts of future OWF development were identified and examined. Such an analysis seems to be a precondition for the more active engagement of local stakeholders in the debate on the ways in which to best utilize the new opportunities created by the plan and cope with the threats resulting from maritime spatial planning (MSP). The key impacts recognized by the local business stakeholders have been related to landscape pollution and fishing limitations. Stakeholders less frequently have noticed positive impacts of MSP such as development of a new form of tourism. Up to this point, small municipalities have not undertaken sufficient action, and there is a lack of communication between developers, marine planners and coastal communities. Planners have not assessed the impact of their plan on local economic development. The proposed remedies cover standard actions related to communication, education and dialogue, but in addition to that, a consolidated action of local municipalities on how to capitalize on OWF development has been proposed. The first step proposed is preparation of a joint strategy by coastal municipalities addressing this issue.
\end{abstract}

Keywords: maritime spatial planning; offshore wind development coastal municipalities; Poland; social acceptance

\section{Introduction}

Maritime spatial planning (MSP) is considered a relatively fresh territorial governance mechanism [1]. The sea represents a new domain of spatial planning, and the ambition of MSP is to link the spatial development of sea and land [2]. According to the EU MSP directive [3], until March 2021, the entire sea space under the jurisdiction of EU countries should be covered by maritime spatial plans. In many countries, MSP is driven by global concerns, including, among others, climate change. Resultantly, vast sea areas in EU territory have been allocated for offshore energy generation [4]. Undoubtedly, such a spatial decision will influence development on land. However, this development runs a risk of failure if it disregards the needs and concerns of the local population and if local stakeholders are unaware of the opportunities and threats related to MSP. Thus, MSP should be accompanied by actions taken at the local level, as in the case of Agenda 2030 [5]. In this context, local leadership and the local public choice process, i.e., a proactive attitude shown by the local administration [6], are of utmost importance. Yet, in many MSP cases, these elements are absent and MSP remains a top-down process [7].

The Polish maritime spatial plan was adopted in May 2021. More than $8 \%$ of Polish sea areas are allocated to offshore energy. According to the Polish National Energy Strategy, by 2030 , there will be approximately $5.9 \mathrm{GW}$ and by 2040, between 8 and 11 GW capacity installed at offshore wind farms [8]. This offshore boom partially stems from the recently enforced policy inhibiting the construction of wind farms on land as a result of several 
negative externalities, such as landscape pollution, impact on the health of local citizens, etc. One of the reasons behind the setback was the implementation of the $10 \mathrm{H}$ rule, which requires a minimal distance, from the wind device to the nearest building or natural protection areas, of at least ten times the height of the device [9]. Such a policy shift is expected to become a game-changer, shifting the production of wind energy from land to sea.

The problem is that the economic impacts of MSP have never been addressed, systematically, on a local scale. Moreover, overshadowed by more significant impacts, e.g., those linked to climate change, several others have been forgotten entirely. Yet, such "hidden" impacts will appear at separate geographical scales and with different time lags. For instance, as MSP remains the responsibility of Poland's national government, in preparing the key local assumptions, the local and even regional consequences have not been considered carefully. Consequently, without the proactive approach of the stakeholders affected by them, the local or regional impacts would remain unclear. However, the time lag between the adoption of the maritime plans and their actual results renders those stakeholders falsely calm and unaware. They are unable to estimate or make an informed guess on the goods and bads resulting from MSP development. Without previous relevant experience, they lack sufficient knowledge and know-how regarding the essence and magnitude of these impacts that influence their welfare. Thus, they may remain unprepared and unable to take part in policy discussions, and, when the impacts appear, it may prove too late to require an overhaul of the policy set-up. Such a turn of events will negatively influence development at a local scale.

Resultantly, this paper aims at identifying the aforesaid MSP impacts (related to offshore energy) at a local scale and mapping the local business stakeholders' perception of them (in Poland). It suggests and tests a structured approach for fulfilling these objectives. Local scale is defined in terms of the proximity to offshore wind farms (coastal areas neighboring farms) and the scale of the business operations of the enterprises (local businesses).

This paper is a Polish contribution to the ongoing discussion of the various impacts of MSP and OWF development. The majority of these investigations have been done at a macro and meso-scale, e.g., the research of Jenniches, Weig and Schultz-Zehden, Aitken and Kannen and Ratter, among others [10-13]. The problem is that, with the exception of Jenniches, who demonstrated how to measure the regional economic and environmental impacts of terrestrial wind energy development by taking into consideration the differences in the environmental and socioeconomic structure among the regions/territories affected [10], these studies were not spatially explicit. A number of studies that focus on the local stakeholders' perceptions of OWFs or MSP exist as well. For instance, Kermagoret et al. examined stakeholder perceptions of the social, ecological and economic impacts of OWFs on the local communities of the Bay of Saint-Brieuc in France [14]. Similar studies have been conducted at a meso-scale [15]. However, these studies focused mainly on the identification of perceptions and the acceptance mechanisms. The added value of this paper consists of linking these two different perspectives: the one related to the stakeholders' minds and the one concentrating on local territorial development. The logic is the following: the mapping of perception informs public choice, public choice influences market decisions, inducing development at a local scale, and this changes the attitudes of stakeholders accordingly, providing a feedback loop in the entire process.

\section{Research Strategy, Methods and Setting the Scene}

The following research strategy was adopted in this paper. Firstly, based on the literature review, the positive and negative economic impacts of OWF development at a local scale were identified. Secondly, relevant local business stakeholders in Poland potentially affected by OWF development were pinpointed and their stakes analyzed. The selection of stakeholders was based on their input in the local development (representativeness of the economic structure of the local areas analyzed). Stakeholder mapping allowed for the distilling of OWF impacts that are relevant for key local stakeholders driving local develop- 
ment. Then, this information was used for conducting in-depth interviews which led to the identification of the local stakeholders' awareness regarding the risks and opportunities created by OWF development, as well as to the assessment of their level of preparedness.

Finally, the stakeholders' opinions and knowledge were juxtaposed with the experiences of other countries in which offshore wind farms are operating on a large scale. All these factors served the aim of formulating conclusions on the necessary steps that would lead to local coastal communities in Poland being better prepared to more vigorously exploit the benefits of offshore wind farm development and mitigate or adapt to impacts that negatively affect the area's welfare. The methodological scheme is presented in Figure 1.
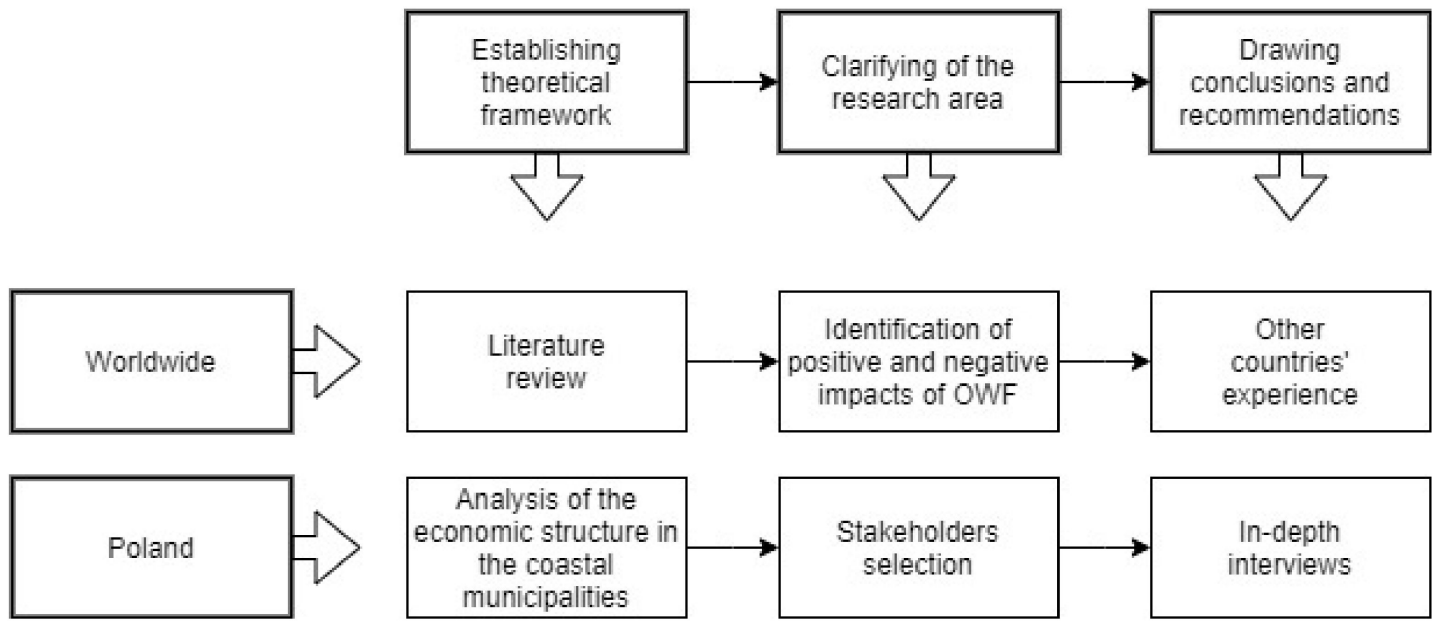

Figure 1. Methodological scheme.

\subsection{Good and Bad-Literature Review and Theoretical Framework}

The relevant literature demonstrates that, despite the careful engagement of stakeholders, offshore wind farm development still brings both benefits and burdens. The most thoroughly researched negative impact at the local scale, extensively discussed even before the deployment of OWF installations, has been the aesthetic issue [16], otherwise referred to as landscape industrialization. According to the study conducted by Sullivan et al. in 2011 in the Irish Sea and North Sea (on 11 offshore facilities that varied from $80 \mathrm{~m}$ to $126 \mathrm{~m}$ in rotor diameter size), in different weather conditions, moderately sized (in terms of number of turbines) offshore wind facilities may be visible from distances exceeding $35 \mathrm{~km}$. Smaller wind facilities were judged to be easily visible at distances of $22-25 \mathrm{~km}$ [17]. Since the research, the dimensions of installed offshore facilities increased and can be more than double the size of the facilities observed in 2011, the GE's Haliade- $X$ with its $220 \mathrm{~m}$ rotor diameter representing such an example. Alongside the number of turbines and OWF area, the study on the efficiency of European offshore wind farms counts the distance to shore as one of the key factors determining landscape pollution. For the purposes of assessing the impact score, the distance from shore ranging between $20-30 \mathrm{~km}$ is scored as 3 (where 5 is the maximum score and 1 is the minimum score for a distance exceeding $40 \mathrm{~km}$ ) [18]. Landscape industrialization may result in a significant welfare loss [19]. According to Gee, the threat to the open horizon posed by the presence of an offshore wind farm could produce feelings of anxiety among people emotionally tied to the sea [20]. Other key problems prominently highlighted in the relevant literature concern the visual impact of OWFs on the recreational demand for the beach. Voltaire et al. conducted a wide survey among Catalonian tourists to estimate the loss in prosperity that may result from a shift in beachgoer behavior [19]. The study proved that the potential economic loss in touristic regions is significant but depends on the distance to shoreline and density of turbines within one project [19]. While researching public acceptance of OWFs, Roddis et al. also acknowledged that visual pollution may impact local tourism (including employment) and 
the price of local property [21] as well. The potential negative impact of Southern England's Navitus Bay offshore wind farm on the landscape represented one of the reasons for its rejection [18]. This effect on the landscape was also the reason for Polish legislators banning offshore wind farms in Polish territorial waters (up to 12 miles from the shore) [22].

Another important negative impact is related to the permanent exclusion of other sea sectors (exclusion effect). As navigation barriers, farms may cause diversions of shipping (rerouting): "Diversion can lead to following problems for the shipping sector: (1) Increased time and fuel spent, more greenhouse gas emissions, higher wages for the crew; (2) Financial penalties from the charter; (3) Higher insurance costs due to riskier routes; (4) Compliance with national and international law. Some countries have areas where certain restrictions apply, such as PSSAs in the Baltic; (5) In the case of short sea shipping, longer transit times may make short sea services unable to compete with landbased transport services" [23]. By the same token, fishing can be banned in the OWF areas or at least regulated. The restriction of fishing leads to conflicts with the fishing industry [24]. The exclusion of areas from fishing directly translates to a loss in the fishers' revenue, particularly for small-scale fisheries. OWFs might also exclude mining and the placing of communication cables in areas that belong to the farms.

The construction of OWFs may also result in new and direct negative impacts on sea environment and ocean functioning. The ecological risks of OWFs were identified by Roddis et al. [21], as well as in numerous other studies [25-27]. In particular, serious concerns have been raised in terms of the well-being of mammals and migrating birds. A number of researchers have also discussed [27] the possible implications of energy withdrawn from the OWF area (sea air) and the shape of the seabed undergoing a change that may alter existing sea currents and, subsequently, sediment transport, resulting in coastal erosion. The same authors have also identified various chemical risks related to the intensification of oil spills that occur from OWF construction and maintenance, leaks of ammonia (working fluid in a closed OWF system), toxic for sea species, leaching of toxic compounds from anti-fouling paints that are used to minimize the biological fouling of pillars. Finally, electromagnetic fields around transmitting cables and other facilities could compromise the navigation of species sensitive to electro- or magnetic fields, primarily fish [28].

Direct costs (direct effect of OWFs) are imposed on other sectors as well. In the case of OWF semi-closure, negative impacts on the fishery sector may include: accidental damage and ship strikes, snagging fishing gears and obstruction of navigation routes to and from fishing grounds [29]. Fishers' concerns are also related to water cables disrupting fishing efforts. Furthermore, OWFs may limit leisure tourism (e.g., sailing) [18] and discourage sailing through OWF areas, as well as reduce navigation safety in general [30].

Finally, several authors identified social and distributional justice as an issue. Kannen and Ratter focused on the high uncertainty that stems from social and ecological impacts, characterizing marine planning as "planning under uncertainty" [13]. The usually topdown and centrally supported OWF location processes that affect local societies may threaten the latter's integrity and normal functioning. If such processes radically change the social set-up by introducing new and powerful actors, they create an additional burden rather than an opportunity [31].

However, the list of positive impacts is long as well. The most prominent are direct ones concerning the creation of new local jobs and employment opportunities (a direct effect of OWFs). According to official estimates, the investment could generate more than 70 thousand jobs in Poland and a PLN 15 bln inflow to the central budget before 2030 [32]. Maintenance and service, responsible for nearly $19 \%$ of the total cost, form the largest part of cost breakdown in OWF investment. Operations including compensation payments, training, onshore and offshore logistics and health and safety inspections are responsible for $9.3 \%$ of the total investment [32]. The value of maintenance and services needed to support Polish offshore farms over the years will amount to approximately PLN 4 bln and operations another PLN $2 \mathrm{bln}$. The local companies could benefit greatly since all 
these services can be provided locally. Local port facilities can offer room for the providers of these services. Thus, sectors that are traditionally linked to local economy, such as the fishery sector, for instance, but seaport services and their infrastructure could also be potential beneficiaries. They can be included in the offshore wind farm supply chain. Additionally, farms could become a suitable place for the development of mariculture activities, facilitating the further diversification of the local economic base. There will be a multiplication effect as well. New employment will increase the demand for local goods and services, at least partially driving up the demand for goods and services offered in local stores and other service facilities. Moreover, due to an increase in income tax revenues, partially acquired from municipal budgets (at least in Poland), a portion of these benefits will be channeled into the budgets of local coastal municipalities. Power connectors, from the sea to national grid, will be located near the shore as well, providing additional income from property tax. Richer local communities will be able to better support local development.

Landscape industrialization may have some positive implications as well. OWFs could attract tourists interested in visiting the farms, allowing for the development of new forms of tourism, e.g., recreational boating or short sea-touring [33] operated by local companies.

The environmental benefits are related mainly to the climacteric ones [31]. Access to clean energy would improve the image of local tourist places and attract new tourists and inhabitants. OWFs have numerous positive impacts on marine and coastal habitats (habitat effects). For instance, the farms may act as artificial reefs. Research has shown that artificial reefs may exert a restorative effect on degraded natural habitats [25]. The macroalgal habitat in the Korean peninsula, created from artificial reefs, represents such an example. OWF pillars could offer new opportunities for mussels and benthic species. The result is increased biodiversity but also an improved ecological situation of sea waters stemming from the filtrating services provided by shellfish. The enrichment of biodiversity could provide an opportunity for recruiting commercially valuable marine species, a byproduct recognized as the "reef effect", identified in the North Sea [34]. A sheltering effect is a yet another benefit [28]. Because of the restriction of navigation or fishing within the farms, larger-scale OWF areas will act as maritime protected areas. "Thus, they may serve as recruitment sources for the adjacent fishing areas" [27]. As a result, fishers will be granted access to more abundant fish stock in the long run [35]. However, one should note that, while the artificial reef may stimulate some species, it may adversely affect others [36]. However many of these ecological benefits could also translate into additional economic ones, as in the case of fisheries or by attracting tourists and new inhabitants. For example, an artificial reef may attract divers and result in the development of local diving companies [35].

The social benefits are related mainly to the support of weak social groups. As proved by the research, many groups of fishers are content with receiving compensation for restrictions in access to the fishing grounds. A number of authors [35] also mention modernization opportunities, i.e., the inflow of new know-how, better prospects for the development of local start-ups due to increased awareness on a local scale and an improved local economic situation (i.e., diminishing outflow of young, well-educated people, inflow of top specialists, etc.).

All the impacts identified in this section are summarized in Table 1. They are grouped according to the well-known energy trilemma, which refers to the trade-offs between economic impacts, environmental impacts and social/civic impacts [37]. 
Table 1. OWF positive and negative impacts on a local scale.

\begin{tabular}{|c|c|c|c|}
\hline Type of Impact & Source of Impact & Negative & Positive \\
\hline \multirow{4}{*}{$\begin{array}{l}\text { Impact on local } \\
\text { economic } \\
\text { development }\end{array}$} & $\begin{array}{l}\text { Landscape } \\
\text { industrialization }\end{array}$ & $\begin{array}{l}\text { Discouraging beachgoers and other } \\
\text { types of coastal tourists } \\
\text { Negative impact of a decrease of local } \\
\text { tourism on other local industries } \\
\text { Reducing prices of coastal real estate }\end{array}$ & $\begin{array}{l}\text { Attracting new tourists interested in } \\
\text { seeing OWF } \\
\text { Positive multiplication effect from } \\
\text { local tourism to other local industries }\end{array}$ \\
\hline & Exclusion effect & $\begin{array}{l}\text { Higher costs of navigation, diverting } \\
\text { navigation from local ports near OWF } \\
\text { Closing traditional fishing grounds } \\
\text { and impeding access to } \\
\text { functioning ones }\end{array}$ & $\begin{array}{l}\text { Increasing abundance of commercial } \\
\text { fish species (sanctuary effect) }\end{array}$ \\
\hline & Direct effect & $\begin{array}{l}\text { Baltica } 3 \text { Accidental damage and ship } \\
\text { strikes, snagging fishing gears } \\
\text { Discouraging leisure tourist sailing } \\
\text { within OWF } \\
\text { Negative effect on navigation safety }\end{array}$ & $\begin{array}{l}\text { New jobs in maintenance and } \\
\text { operation of OWF and in mariculture, } \\
\text { new services in local ports } \\
\text { Increased budgets of the } \\
\text { local communities }\end{array}$ \\
\hline & Habitat effect & & $\begin{array}{l}\text { Increasing abundance of commercial } \\
\text { fish species due to increased } \\
\text { biodiversity. } \\
\text { Cleaner sea waters attracting new } \\
\text { tourists and inhabitants } \\
\text { Attracting new tourists for diving in } \\
\text { OWF area }\end{array}$ \\
\hline \multirow[b]{2}{*}{$\begin{array}{l}\text { Impact on } \\
\text { environment }\end{array}$} & Habitat effect & Changing composition of species & $\begin{array}{l}\text { Cleaner sea waters } \\
\text { Increased biodiversity }\end{array}$ \\
\hline & Direct effect & $\begin{array}{l}\text { Risk of erosions } \\
\text { Risk of chemical pollution } \\
\text { Direct threats to migrating birds, } \\
\text { mammals and some fish species }\end{array}$ & \\
\hline \multirow{2}{*}{$\begin{array}{l}\text { Impact on local social } \\
\text { well-being and } \\
\text { decision-making } \\
\text { process }\end{array}$} & $\begin{array}{l}\text { Landscape } \\
\text { industrialization }\end{array}$ & & $\begin{array}{l}\text { Feeling of anxiety among people } \\
\text { emotionally tied to the sea }\end{array}$ \\
\hline & Social effect & $\begin{array}{l}\text { Political encroachment compromising } \\
\text { social justice }\end{array}$ & $\begin{array}{l}\text { Opportunity for modernizing coastal } \\
\text { societies } \\
\text { Support for weak social groups }\end{array}$ \\
\hline
\end{tabular}

\subsection{Stakeholder Mapping-A Short List of OWF Impacts}

In order to establish a link between the perceptions of local stakeholders of OWFs and the process of local development, the economic structures of the local areas affected by OWFs were analyzed first. On this basis, the relevant group of stakeholders, i.e., those driving local economic development, was identified.

OWF farms will be located primarily in the north-central part of the Polish sea waters. Based on the proximity to OWF investments, 8 municipalities were identified as areas locally impacted by OWF development: Darłowo, Postomino, Ustka, Smołdzino, Łeba, Choczewo, Krokowa and Władysławowo.

Table 2 presents the basic characteristics of the selected municipalities, thus providing a general overview; they have low population density and are short in resources when compared to bigger urban agglomerations. The number of inhabitants of the 8 municipalities combined is less than $40 \%$ of Gdynia's population ( 244 thousand inhabitants) and less than $20 \%$ of Gdańsk's (559 thousand inhabitants). 
Table 2. List of the 8 municipalities and their basic characteristics. Source: own study based on Statistics Poland data.

\begin{tabular}{|c|c|c|c|c|c|}
\hline Municipality & $\begin{array}{l}\text { Number of } \\
\text { Inhabitants }\end{array}$ & Area $\left(\mathrm{km}^{2}\right)$ & Urban Density & $\begin{array}{c}\text { Budget (PLN } \\
\text { Thousand) }\end{array}$ & Seaport \\
\hline Władysławowo & 15,388 & 42 & 366 & 98,908 & Yes \\
\hline Krokowa & 10,816 & 214 & 51 & 69,812 & No \\
\hline Ustka city & 15,367 & 10 & 1537 & 92,562 & Yes \\
\hline Ustka rural municipality & 8339 & 227 & 37 & 51,153 & No \\
\hline Darłowo rural municipality & 7949 & 269 & 397 & 64,893 & Yes \\
\hline Darłowo city & 13,695 & 20 & 51 & 81,045 & No \\
\hline Postomino & 6891 & 227 & 30 & 51,176 & No \\
\hline Choczewo & 5495 & 183 & 30 & 29,734 & No \\
\hline Łeba & 3675 & 15 & 240 & 29,738 & Yes \\
\hline Smołdzino & 3398 & 260 & 13 & 16,479 & No \\
\hline
\end{tabular}

According to the research of Szejgiec-Kolenda et al., maritime economy has been developed intensively only in certain areas of the Polish coast [38]. In general, the area surrounding the Gulf of Gdańsk is more developed than the northern coast, in which the eight selected communes are located [38].

As presented in Figure 2, the tourism sector plays a key role in the economy structure [38] of small coastal communities. In the latter, many individuals earn a living from their privately owned guesthouses, run as family businesses. During the 3-month summer season, touristic coastal cities are inundated by crowds of visitors, leading to seasonal profits for the habitants, revenues that constitute the main source of total annual income. In 2019, more than 600 thousand tourists visited the abovementioned 8 municipalities [39]. The statistics are drawn from official data which may not necessarily reflect reality as it does not include zones that are not officially registered. As such, the numbers in reality may be greater. For instance, on Booking.com, the total number of advertisers is much higher than in the official statistics. Table 3 presents a comparison of each municipality's basic data on tourism with the data collected from Booking.com. The data show the level of entrepreneurship in tourism as well as the sector's vast importance for coastal municipalities. According to official statistics, these municipalities have a combined number of 740 accommodation facilities, while Booking.com data indicate a higher number of more than 1200 facilities.

Table 3. Tourism in coastal communities. Source: my own study based on the maritime economy statistical data of 2019 and my research on Booking.com (accessed on 26 April 2020).

\begin{tabular}{ccccc}
\hline Municipality & $\begin{array}{c}\text { Number of } \\
\text { Accommodation } \\
\text { Facilities (2019) }\end{array}$ & $\begin{array}{c}\text { Number of } \\
\text { Accommodations } \\
\mathbf{( 2 0 1 9 )}\end{array}$ & $\begin{array}{c}\text { Number of } \\
\text { Tourists Annually } \\
\text { (2019) }\end{array}$ & $\begin{array}{c}\text { Number of Accommodation } \\
\text { Facilities According to } \\
\text { Booking.com (2020) }\end{array}$ \\
\hline Władysławowo & 349 & 17,410 & 255,318 & 566 \\
Łeba & 137 & 10,703 & 121,815 & 267 \\
Krokowa & 62 & 2245 & 17,752 & 8 \\
Ustka & 72 & 7085 & 58,171 & 293 \\
Darłowo & 67 & 6932 & 81,031 & 108 \\
Postomino & 33 & 4837 & 63,864 & 93 \\
Choczewo & 18 & 496 & 5414 & 11 \\
Smołdzino & 2 & 89 & NA & 10 \\
\hline
\end{tabular}




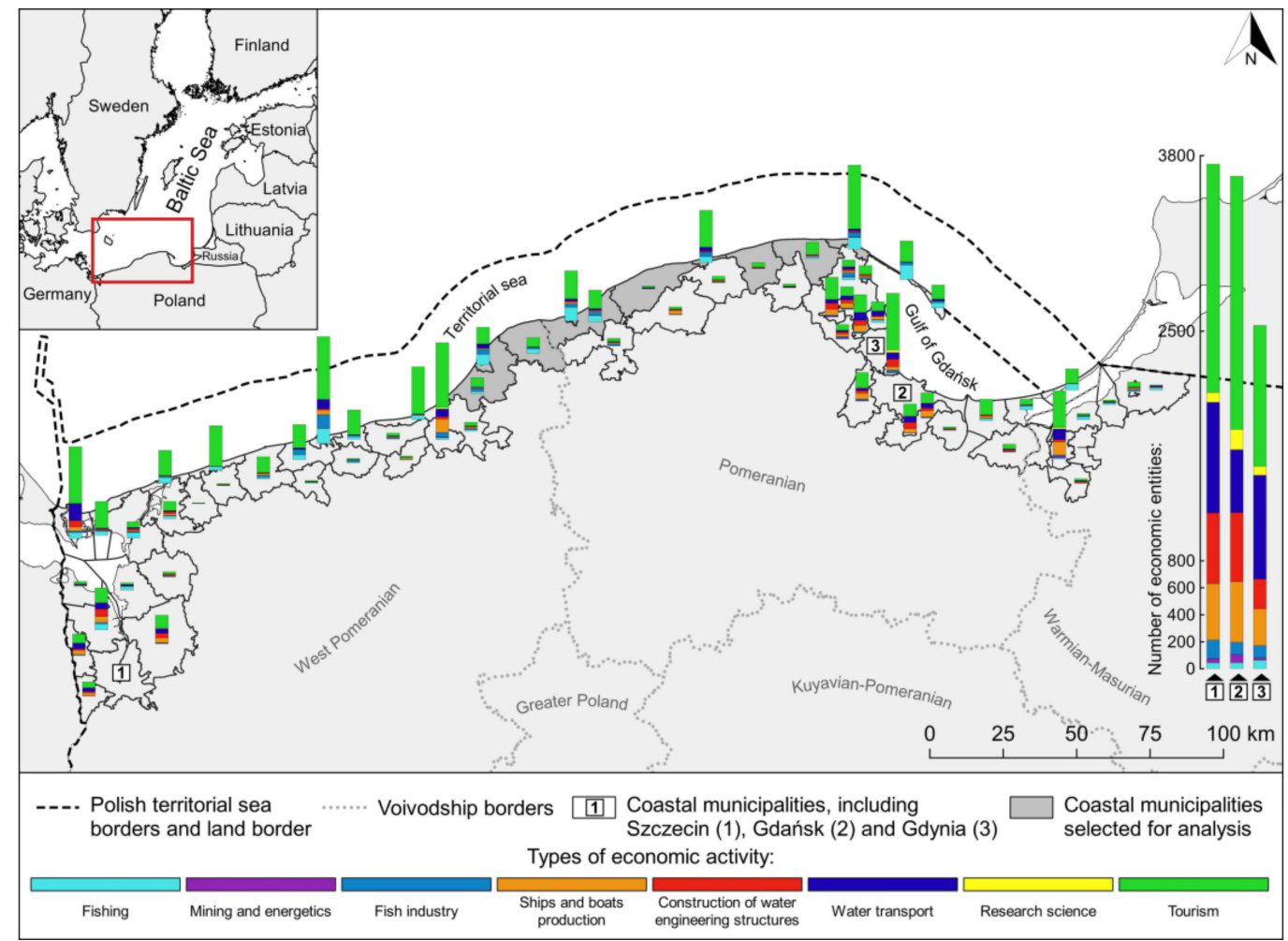

Figure 2. Number of maritime economy entities in coastal communities in 2016. Source: own study based on Statistics Poland data.

The fishery sector in Poland is under significant pressure, following numerous regulations and limitations on catches, such as the establishment of quotas on the latter. Fishers have become more skeptical and wary of any new limitations placed on their fishing areas [40]. This situation has resulted in a steep decline in fishery fleet as well as in an overall decline in this particular sector of the local economy. However, it has also made fishers sensitive to OWF development [40]. Water transport plays a relatively important role in the economy of several of these municipalities. Four (4) municipalities have one seaport each within their territory, while the municipality of Ustka has two. According to existing analyses, the port of Ustka is the most suitable for servicing OWFs [41].

In conclusion, tourism, fishery and water transport are the main engines of development for these municipalities, which offer the largest rent from marine space utilization to their citizens [42]. Therefore, the perception of the OWF impact on local development was conducted on the basis of the opinions of stakeholders from these sectors.

In line with the above analysis, all impacts have been selected from a literature review that is relevant to these key economic sectors, or drivers of local development, in the investigated area. This selection is presented in Table 4.

Table 4. OWF positive and negative local economic impacts for discussions among local stakeholders.

\begin{tabular}{|c|c|c|c|}
\hline Impact & Tourism & Fishery & Water Transport \\
\hline \multirow[b]{2}{*}{ Positive } & $\begin{array}{c}\text { Attracts new tourist interested } \\
\text { in OWF }\end{array}$ & $\begin{array}{l}\text { Increases abundance of } \\
\text { commercial fish species } \\
\text { (sanctuary and habitat effects) }\end{array}$ & New services in local ports \\
\hline & \multicolumn{3}{|c|}{$\begin{array}{c}\text { Creates new types of jobs related to the maintenance and operating of OWF, development of mariculture, } \\
\text { development of new types of tourism (diving, OWF sea-touring, etc.) and development of ports. } \\
\text { Presents the opportunity to modernize coastal societies. } \\
\text { Supports weaker social groups. }\end{array}$} \\
\hline
\end{tabular}


Table 4. Cont.

\begin{tabular}{|c|c|c|c|}
\hline Impact & Tourism & Fishery & Water Transport \\
\hline \multirow[t]{2}{*}{ Negative } & $\begin{array}{l}\text { Discourages beachgoers and } \\
\text { other types of coastal tourists } \\
\text { due to landscape } \\
\text { industrialization }\end{array}$ & $\begin{array}{l}\text { Closes traditional fishing grounds } \\
\text { and impeding access to the } \\
\text { functioning ones. } \\
\text { Causes accidental damage and } \\
\text { ship strikes, snagging } \\
\text { fishing gears. }\end{array}$ & $\begin{array}{c}\text { Increases navigation costs, } \\
\text { diverting navigation from local } \\
\text { ports near OWF. } \\
\text { Diminishes the number of leisure } \\
\text { tourists sailing through local } \\
\text { ports (making stop-over there). }\end{array}$ \\
\hline & Encourages politi & 1 encroachment compromising soci & 1 justice (uncertainty) \\
\hline
\end{tabular}

\section{Engagement of Stakeholders in Policy Processes in Poland}

Wind farms have been introduced to Polish maritime areas by two parallel efforts. The first one was related to maritime spatial planning while the second was of a sectoral character.

In Poland, OWFs were mentioned for the very first time in 2011 in strategic documents. Though the pilot plan for the Middle Bank was of an informal character, it clearly signaled the possibility of the emergence of OWFs. This document has not been widely discussed, however, and has thus remained known only among planning professionals. In 2016, the Study of Conditions of Spatial Development of Polish Sea Areas [41] was prepared by order of the Polish Maritime Administration. In this document, one chapter was devoted to the development of OWFs in Polish marine areas. Subsequently, the Maritime Authorities compiled the Polish maritime spatial plan, reserving marine space for a minimum of $11 \mathrm{GW}$ of offshore wind energy, a figure that totals $8 \%$ of Polish marine areas, approximately $2342 \mathrm{~km}^{2}$ [22]. Figure 3 presents the areas designated for OWF deployment (14.E, 43.E, 44.E, 45.E, 46.E, 53.E, 60.E), the small coastal municipalities selected for the present research, the vessel routes and the catches within the area.

The abovementioned study and plan were both subject to numerous discussions. The plan could be accepted or rejected, but, if rejected, it was required that the reasons must be clearly specified and posted on the official Maritime Administration website. OWF developers actively participated in this process. Local business stakeholders (fishers, representatives of tourism industry) were active as well, but, surprisingly, they raised only a few concerns regarding OWFs. Fishers, on the other hand, feared a potential exclusion effect as well as the creation of barriers to their traditional fishing ground. A separate meeting was organized to reach an agreement between fishers and OWF developers concerning the placement of fishing restrictions during construction and the operation of farms. Other local businesses highlighted conflicts related to the construction of a nuclear power plant, gas pipelines and typical tourist infrastructure (marinas, piers, seaside boulevards, etc.). However, the most active here were local authorities. The latter were solely concerned with the development of the tourism sector while neglecting any other opportunities for development that were provided by the plan [22]. Landscape pollution went unmentioned during public debates and public hearings. Discussions on local ports were limited to the topics of exclusion effects, such as the limited access of ships from the northern direction due to OWF construction, but only a small number of port authorities were really active. Current research from the Maritime Institute in Gdańsk and Södertörn University in Stockholm on the social sustainability [43] of Polish maritime spatial planning indicates that the low participation of local stakeholders may be partially due to communication barriers and low awareness of the plan's consequences on their welfare. 


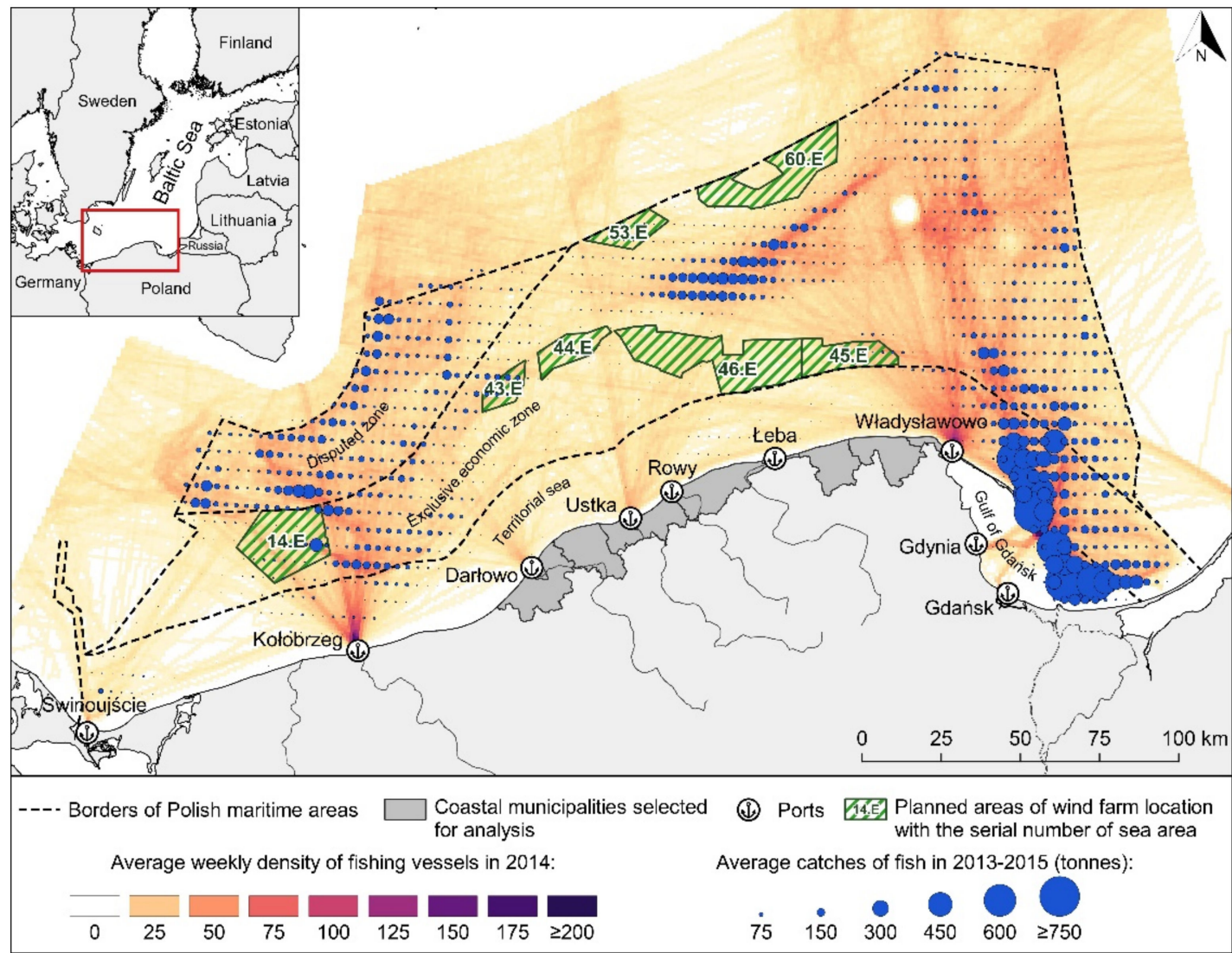

Figure 3. Average weekly density of fishing vessels and average volume of catches in the area of future OWF projects. Source: own study based on data shared by Maritime Office in Gdynia and HELCOM.

Several sectoral actions have been launched in tandem. Since 2012, the OWF sector has undertaken numerous efforts to provide information on OWF deployment (various activities of Polish Offshore Wind Energy Society (PTMEW), e.g., Offshore Academy). One of the most important was the PTMEW project, where public participation in the development of sea area plans was implemented under the program "Citizens for Democracy". It was designed to stimulate public discussion and involve key local stakeholders in the introduction of OWF to Polish marine areas. It was composed of various informational meetings in selected seaside urban centers, which took the form of seminars with the participation of local community representatives, OWF industry and the maritime administration. However, it seems that these efforts had a limited impact on the attitude of local stakeholders, who seemed to mix up various sea governance processes. For instance, they saw maritime spatial planning as being in the interest of OWF developers [44]. The OWF sector has also successfully lobbied for the support of Polish key decision-makers. On January 2021, after two years of discussions and various draft proposals, the Polish special offshore bill [45] was adopted by the Parliament. It provides numerous supportive measures aiming at the enhancement of offshore energy investments. The bill also contains several so-called local content rules, based on the UK's solutions, in order to support local businesses [46]. It requires investors to describe their planned investment with Polish entities [45]. However, the bill does not provide specifications for the location of the entity; thus, the only requirement regarding the entity is its registration or the registration of one of its branches in Poland. There is no differentiation among contractors with regards to their location. The entire economy is perceived as a whole, without lending the local perspective more prominence. It seems that the preparation of the bill failed to profoundly engage local business stakeholders. The national public administration and the representatives of the OWF sector were the dominant actors in the preparation process of the bill. No 
local consultations were offered, and no local effects (except some positive direct ones) were considered.

\section{Polish Stakeholders' Perception of Impacts and Proposed Ways of Coping with Them}

In order to gauge the complexity of the current perception of OWFs and their potential effects on coastal municipal economies, six representatives from local businesses and four others from the public administration sector, within the municipalities under investigation, were interviewed via in-depth semi-structured interviews. One respondent represented the tourism sector, four the fishery sector, one the offshore sector, two came from local governments, and two from national agencies. The interviews were conducted in the period of 21 October to 26 November 2020.

The interviewees were asked about the general impact of OWF development as well as the key impacts identified in this research. The interviews were conducted, transcribed and analyzed by coding the key elements [47].

The results, using a modified Likert scale, are presented in Figure 4. The respondents could express their level of endorsement by selecting one of five possible statements: "strongly agree", "agree", "neutral", "disagree" or "strongly disagree". Because of the relatively small number of interviews (10), the results may not be considered as representative but may offer new insights into the issues under investigation. Among the respondents, there was a strong agreement regarding OWFs' significant impact on the economies of the affected coastal municipalities (Figure 4). The majority of responses pointed to a positive impact with no clear opinion among the respondents on the potential negative impact (Figure 4).

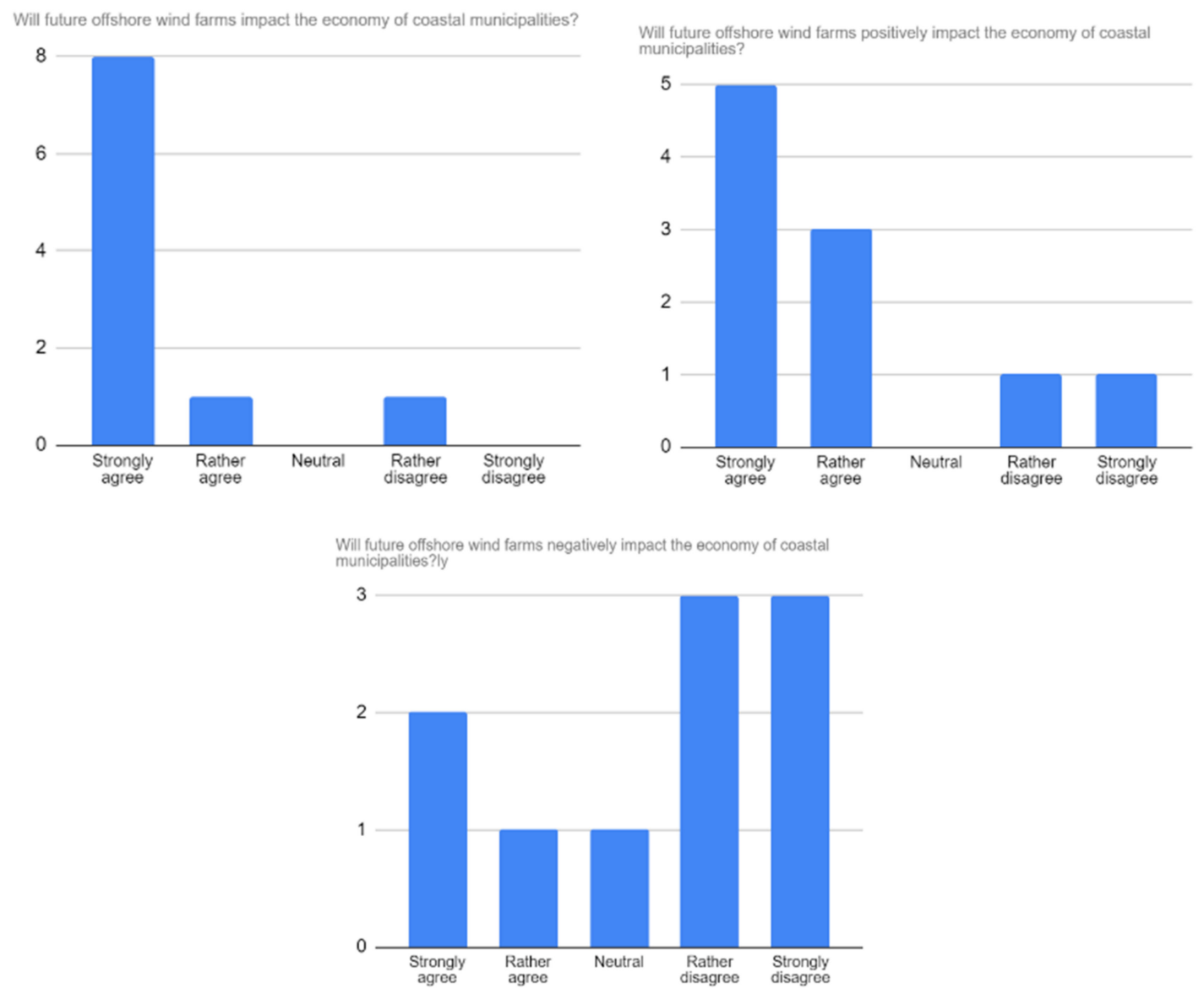

Figure 4. Results from interviews with stakeholders measured by Likert's scale. Own research. 
The respondents were asked six open-ended questions regarding their awareness of the impact of OWF projects on local business stakeholders. The three main topics were discussed intensively by all respondents, who expressed clear opinions on the negative and positive impacts of OWF development as well as potential coping mechanisms.

Major concerns among respondents regarding the negative impact on the local economy included specifically landscape pollution and possible restrictions to the fishing industry. Thus far, developers have failed to properly and directly address any expected impact on the landscape, leading to confusion and very disparate opinions among locals: "In terms of imagery, these windmills make a macabre impression on me" (local business) versus "it seems to me that they add a certain charm and modernity" (fisherman). Among locals, the landscape is perceived as valuable due to their emotional bond to the seascape and the touristic sector. This further supports concerns regarding fisheries: "When it comes to Łeba, the fishermen are the most affected, because windmills will take these areas from us" (fishermen). There is a general consensus among fishermen on their compensation expectations due to restrictions in fishing zones: "And it is definitely about compensation, fishermen count on it, everything is taken from us-fishermen, we use it and we have income from it. When one fishery limits the catch or closes it, we lose the income" (fishermen). Fishers are willing to relinquish fishing areas in exchange for proper compensation: "If there will be compensation, everyone will forget about these restrictions in fisheries" (fishermen). There are positive opinions as well, though not expressed by fishers themselves: "Paradoxically, it may be that natural reefs are formed between these windmill poles and there will be more of these fish" (public authority).

Businesses seem to be distrustful of investors, something which may cause potential obstacles in terms of the businesses' participation in the distribution of potential benefits. However, expectations on potential benefits from OWF development are still popular among respondents: "The local government should act in the direction that there should be as many benefits as possible for local societies" (local business).

Uncertainty and lack of trust in political decisions, i.e., fear of political encroachment, is a key concern among respondents. The low level of information on potential business opportunities and the necessary requirements to win a contract create anxiety among fishermen: "Here, only tiny units could be used, (. . ) But other activities are more like dreams. Łeba will not benefit from it, Ustka-more likely, it has greater depths in port and if there are no Poles, they will take Danes or Germans who already have experience" (fishermen). "People in all seaside towns don't know what's going to happen, and lack of knowledge is the worst" (fishermen).

Most of the respondents confirmed being aware of future OWF development: "So far it was all held back, in the realm of dreams, and now I can see that there is a sharp acceleration" (public authority). However, poor communication between stakeholders is noticed: "Misinformation, we don't know if this will have an impact on fish populations or port traffic, so people are careful" (fishermen). The results in Table 4 reveal that, out of several positive impacts collected, local stakeholders recognized only two of them, related to artificial reefs and fishers' support (weak social group). With the exception of one navigation-related impact, negative ones were more easily recognized. Local public authorities seem to be unaware of them.

As far as remedies are concerned, local business representatives expressed apprehension regarding the improvement of knowledge: "Investor companies should begin actively operating in local communities. In order to build a positive image of these enterprises, (... ) and show what the benefits for the region will be" (local business). However, others oppose this idea: "The commune should act, make people aware, but not through the investor who will butter us up" (fishermen); "It's obvious that the investor will strongly encourage OWF development and will show only its positive aspects ( . . ) and will not disclose what threatens us" (fishermen); and "they may tell us what will be convenient for them" (fishermen). Therefore, many interviewees emphasized the role of local government as a mediating agent between locals and investors, but this role could prove difficult since 
the problem is highly complex and small communes may lack competences. Respondents do not feel confident in their own representatives' abilities to create fair round-table discussions: "This local government is here to work for our benefit, our society, and I am afraid it is not being done the way it should" (local business). Until now, commitment and cooperation among local governments on that issue have not been observed; on the contrary, some signals indicate that municipalities compete with each other. One interlocutor noticed: "Unfortunately, these local governments do not cooperate. They compete, which is very bad" (public authority).

To conclude, these opinions create the impression that local business stakeholders expect two things: a more democratic dialogue with the OWF sector and the local government's proactive engagement, e.g., sharing and building knowledge on the local impacts of OWFs and assisting local business stakeholders in aforesaid dialogue. Such a partnership between local businesses and local public choice processes should improve local level preparedness.

\section{Coping with Negative Impacts-Existing International Experience}

In order to prepare local business stakeholders for a proactive attitude toward OWFrelated MSP impacts, the existing international experience suggests applying the dialogue process (social learning), in which developers and maritime administration communicate directly with the locals [13]. Yet, due to an asymmetry of power, this is not an easy task. In general, the integration of local stakeholders in maritime spatial planning is considered to be a complex and demanding task [48]. Public spaces, policy round tables and educational programs are required in order to fill the knowledge gap and prepare the actors to participate in the process [49]. Several analyses exist of the methods of engaging local stakeholders in the processes bridging MSP and local development [32]. Participative governance is of utmost importance [50]. Maritime administration should pay more attention to the distribution of goods and bads stemming from MSP [50]. Another highly significant aspect is the support of local stakeholders, specifically the facilitation of their networking by the local public administration for the purposes of building their preparedness and strengthening their negotiation and bargaining power. The German experience best illustrates this idea. In order to offer all the functions demanded by offshore wind operators, under the LO-PINOD framework, a few German ports in Schleswig-Holstein created a common strategy in response to an OWF project located in their vicinity [50]. Such a strategy allowed them to coordinate their actions and devise an offer of becoming an attractive partner for OWF developers [51]. By joining forces and creating a cluster, German municipalities used their assets, close location and an improved lack of strong infrastructure. Coordinated actions undertaken by regional ports let them lobby using one, stronger voice, which expressed the common goal. The German case is an example showing that the cooperation of a few small seaports can become effective but needs to be established deliberately.

\section{Ways Forward-Recommendations for Public Choice Processes}

The analysis of the three topics raised by the interviews yielded several additional solutions for improving the preparedness level of coastal municipalities. The most important seems to be multi-level governance, i.e., the consolidated action of local municipalities possibly facilitated by an upper level of governments, NGOs and academia. The experience of other countries may inform this type of governance. There is much space to improve and create a platform of cooperation between coastal municipalities so that they may use a collective voice in ensuring the upholding of their self-interests. Such cooperation could continue to evolve organically in a cluster of offshore wind farms, by offering a wide range of services for OWF investors and operators.

The first step entails a common strategy among coastal municipalities on how to capitalize on OWF development and prevent any risks stemming from the process. The strategy should address the identification of business opportunities, an analysis of OWF- 
related risks and opportunities for locals, the conscious development of new competencies and necessary infrastructure and the collection of convincing evidence on potential OWFrelated tourism and fishery losses. In order to ensure the necessary synergies as well as counterbalance the economic power of OWF developers (the overhauling of the strategy building process by the vested interests), this strategy should be jointly developed by all affected coastal municipalities.

Secondly, this strategy should become a vehicle of communication between local communities and OWF developers. The municipalities should communicate their expectations to the developers. This would greatly improve the level of trust and understanding between these small coastal municipalities and investors. In addition, the participation of a social intermediary, such as an NGO or scientific organization, would also prove helpful. Proper preparation for these discussions and provision of credible evidence is of the utmost importance. The failure to take these preparatory steps during consultations with fishers, on various planning documents, is partly to blame for this group's dissatisfaction with the process of marine governance in Poland [44].

Thirdly, the strategy should inform the negotiation of the Polish Offshore Sector Deal, a declaration of good practices and intentions designed to support the national offshore sector. Unfortunately, small coastal municipalities do not seem to have actively participated in the process. The appointment of a dedicated plenipotentiary to represent the interest of coastal municipalities at the national level would be beneficial to counterbalance that of the government and business sector. This plenipotentiary may build an institutional framework that will serve to connect the presently scattered municipalities with multinational institutions, which are currently not addressing the issue of cooperation at the local level.

Finally, this strategy can serve to raise the awareness of local populations on the risks and opportunities of OWF development, a challenging task if one wants to avoid further antagonizing local societies. Similar issues to the maritime spatial planning process may arise, such as the fear of furthering the legitimization of OWF development through participation. This issue must be addressed through the introduction of political trade-offs of cost and benefits, based on the identified conflicts by stakeholders [52].

\section{Conclusions}

The present paper has a twofold objective. The first aim is to identify the potential socioeconomic effects of the development of OWF-related MSP for small coastal municipalities in Poland and the specific conditioning factors. The second aim is to examine the perception of small coastal municipalities and investigate potential methods of increasing their benefits, while preventing risks, from the new types of maritime spatial development as well as propose effective policy and research measures that may lead to an improvement in the level of their preparedness. As far as the second objective is concerned, one can conclude that despite the visible acceleration of MSP in Poland and the indisputable fact that this process will impact coastal communities and their economies sooner rather than later, local societies are simply not prepared to meet the challenge. The main challenges are related to communication, a mismatch in popular knowledge (problems with knowledge integration) and a lack of leadership in structuring the coastal municipalities' response to MSP results, i.e., OWF development. Thus far, the minimal necessary level of trust among the affected actors has not been reached and there is no clear strategy on how to proceed. The clear risk here is that, in the absence of a proactive approach from local communities, the potential benefits may be either reaped by international actors or be divided in an ad hoc manner under the surveillance of the well-organized marine sectors. However, one should note that the current research revealed some limitations of the approach applied. They were related to:

- Data deficits: a lack of credible and recent data on catches (artisanal fishery) and tourism creating problems in assessing the real trade-offs related to OWF development in Poland. 
- The small number of stakeholders who participated in in-depth interviews: for many of the individuals approached, the subject was entirely new and they were unwilling to express their opinions. This may create a research bias in the obtained results.

Finally, this paper reveals several important tasks for the research community. In order to facilitate the preparedness of coastal societies for the new forms of offshore development as well as equip them with the necessary skills and information that will increase their engagement in decisions on strategic trade-offs, new knowledge and knowhow are necessary. The following tasks should be encouraged:

- More in-depth research on various economic, environmental and social consequences of MSP, with a particular focus on OWF;

- Systematic measurement of offshore spatial rent from various maritime uses;

- Organized pressure on improving the collection of available offshore economic data by specialized statistical agencies and launching the collection of data that are not systematically compiled, particularly data relevant to coastal tourism;

- Inventing and testing simple, user-friendly communication of research results that may be of interest to local communities;

- Participating in and facilitating dialogue between coastal communities and business entities in relation to MSP and the development of terrestrial territory;

- Analyzing and disseminating relevant experience from other countries and similar processes.

Neglecting the crucial role and importance of local stakeholders in MSP may become an obstacle rather than an opportunity. Close cooperation between the local government and non-government organizations is required at this juncture in the MSP process. The inclusion of third parties in this process is necessary for creating a suitable platform for democratic discussion without the risk of impartiality. A commitment to better education, information flow and other activities that will lead to an increase in social participation is an investment for a successful long-term relationship with the local community.

The current research should be continued and deepened in the following directions:

(1) The present study should ideally be succeeded by a survey on the perception and preparedness of stakeholders in the small coastal municipalities related to OWF development. This would result in obeying more rigorous standards of representativeness and a more reliable picture of what stakeholders know in fact on the OWF impact (assessment of the stakeholders' knowledge of OWF impact on local development).

(2) Existing databases of Polish enterprises should be used to identify the potential beneficiaries of offshore energy development that can be part of the value chain of the Polish OWFs (as suppliers). The international experience in this field should be investigated, and in-depth interviews with stakeholders should follow.

(3) Finally, in-depth interviews should be conducted with a variety of local stakeholders in order to identify the level of social acceptance, among small coastal communities, of offshore wind farm development. A screening of the general public's opinion is of key importance in this case.

Funding: This research was funded by Polish National Science Centre, grant number UMO-2018/31/ B/HS4/03890. "The APC was funded by Polish National Science Centre".

Data Availability Statement: The individual data underlying this article (interviewees' responses) after anonymization can be shared on request to the author. Data are stored by using an external drive and secured with a password.

Acknowledgments: The preparation of the paper was financed by the Polish National Science Centre under the project "Spatio-economic multiplier in maritime economy" UMO-2018/31/B/HS4/03890.

Conflicts of Interest: The author declares no conflict of interest. 


\section{References}

1. Morf, A.; Kull, M.; Piwowarczyk, J.; Gee, K. Towards a Ladder of Marine/Maritime Spatial Planning Participation. Ocean Coast. Manag. 2019, 177, 200-212. [CrossRef]

2. Kidd, S.; Shaw, D.; Janssen, H. Exploring Land-Sea Interactions: Insights for shaping territorial space. Europa XXI 2019, 36, 45-58. [CrossRef]

3. European Union Directive 2014/89/EU of the European Parliment and of the Council of 23 July 2014 establishing a framework for maritime spatial planning. Off. J. Eur. Union 2014, 2014, 135-145.

4. Junqueira, H.; Robaina, M.; Garrido, S.; Godina, R.; Matias, J.C.O. Viability of creating an offshore wind energy cluster: A case study. Appl. Sci. 2021, 11, 308. [CrossRef]

5. Tremblay, D.; Gowsy, S.; Riffon, O.; Boucher, J.F.; Dubé, S.; Villeneuve, C. A systemic approach for sustainability implementation planning at the local level by sdg target prioritization: The case of quebec city. Sustainability 2021, 13, 2520. [CrossRef]

6. Martínez-Córdoba, P.J.; Amor-Esteban, V.; Benito, B.; García-Sánchez, I.M. The commitment of spanish local governments to sustainable development goal 11 from a multivariate perspective. Sustainability 2021, 13, 1222. [CrossRef]

7. Jones, P.J.S.; Lieberknecht, L.M.; Qiu, W. Marine spatial planning in reality: Introduction to case studies and discussion of findings. Mar. Policy 2016, 71, 256-264. [CrossRef]

8. Ministry of Energy. National Energy and Climate Plan for the Years. 2021-2030. Available online: https://www.gov.pl/web/ klimat/national-energy-and-climate-plan-for-the-years-2021--2030 (accessed on 4 April 2021).

9. Polish Parliament. The Act on Wind Farms Development. Available online: https://isap.sejm.gov.pl/isap.nsf/download.xsp/ WDU20160000961/U/D20160961Lj.pdf (accessed on 4 April 2021).

10. Jenniches, S.; Worrell, E.; Fumagalli, E. Regional economic and environmental impacts of wind power developments: A case study of a German region. Energy Policy 2019, 132, 499-514. [CrossRef]

11. Weig, B.; Schultz-zehden, A. Spatial Economic Benefit Analysis: Facing integration challenges in maritime spatial planning. Ocean Coast. Manag. 2019, 173, 65-76. [CrossRef]

12. Aitken, M. Wind power and community benefits: Challenges and opportunities. Energy Policy 2010, 38, 6066-6075. [CrossRef]

13. Kannen, A.; Ratter, B. Adaptation to change in the North Sea area: Maritime spatial planning as a new planning challenge in times of climate change. Clim. Change Coast 2015, 435-448. [CrossRef]

14. Kermagoret, C.; Levrel, H.; Carlier, A.; Ponsero, A. Stakeholder perceptions of offshore wind power: A fuzzy cognitive mapping approach. Soc. Nat. Resour. 2016, 29, 916-931. [CrossRef]

15. Chen, J.L.; Liu, H.H.; Chuang, C.T.; Lu, H.J. The factors affecting stakeholders' acceptance of offshore wind farms along the western coast of Taiwan: Evidence from stakeholders' perceptions. Ocean Coast. Manag. 2015, 109, 40-50. [CrossRef]

16. Smythe, T.; Bidwell, D.; Moore, A.; Smith, H.; McCann, J. Beyond the beach: Tradeoffs in tourism and recreation at the first offshore wind farm in the United States. Energy Res. Soc. Sci. 2020, 70. [CrossRef]

17. Sullivan, R.G.; Kirchler, L.B.; Cothren, J.; Winters, S.L. Research article: Offshore wind turbine visibility and visual impact threshold distances. Environ. Pract. 2013, 15, 33-49. [CrossRef]

18. Akbari, N.; Jones, D.; Treloar, R. A cross-European efficiency assessment of offshore wind farms: A DEA approach. Renew. Energy 2020, 151, 1186-1195. [CrossRef]

19. Voltaire, L.; Loureiro, M.L.; Knudsen, C.; Nunes, P.A.L.D. The impact of offshore wind farms on beach recreation demand: Policy intake from an economic study on the Catalan coast. Mar. Policy 2017, 81, 116-123. [CrossRef]

20. Gee, K. A place-based perspective on marine and coastal space. Eur. XXI 2020, 36, 1-16. [CrossRef]

21. Roddis, P.; Carver, S.; Dallimer, M.; Norman, P.; Ziv, G. The role of community acceptance in planning outcomes for onshore wind and solar farms: An energy justice analysis. Appl. Energy 2018, 226, 353-364. [CrossRef]

22. Gdynia Maritime Office Maritime Spatial Plan. Available online: https:/ /www.umgdy.gov.pl/?p=38913 (accessed on 14 March 2021).

23. European MSP Platform. Conflict Fiche 7: Maritime Transport and Offshore Wind. Available online: https://www.msp-platform. eu/sites/default/files/7_transport_offshore_wind_kg_1.pdf (accessed on 4 April 2021).

24. Hagos, K.W. Impact of Offshore Wind Energy on Marine Fisheries in Rhode Island. University of Rhode Island Coastal Institute IGERT Project, Narragansett, White Paper in Integrated Coastal Science: 2017. Available online: https:/ /www.researchgate.net/ publication/255606863_Impact_of_Offshore_Wind_Energy_on_Marine_Fisheries_in_Rhode_Island (accessed on 4 April 2021).

25. Draget, E. Environmental Impacts of Offshore Wind Power Production in the North Sea. Available online: https://tethys.pnnl. gov/sites/default/files/publications/WWF-OSW-Environmental-Impacts.pdf (accessed on 4 April 2021).

26. Larsen, J.K.; Guillemette, M. Effects of wind turbines on flight behaviour of wintering common eiders: Implications for habitat use and collision risk. J. Appl. Ecol. 2007, 44, 516-522. [CrossRef]

27. Boehlert, G.W.; Gill, A.B. Environmental and ecological effects of ocean renewable energy development. Oceanography 2010, 23, 68-81. [CrossRef]

28. Bailey, H.; Brookes, K.L.; Thompson, P.M. Assessing environmental impacts of offshore wind farms: Lessons learned and recommendations for the future. Aquat. Biosyst. 2014, 10, 1-13. [CrossRef]

29. European MSP Platform. Conflict Fiche 5: Offshore Wind and Commercial Fisheries. Available online: https://www.mspplatform.eu/sites/default/files/5_offshore_wind_fisheries_1.pdf (accessed on 4 April 2021). 
30. Mehdi, R.A.; Schröder-Hinrichs, J.U.; van Overloop, J.; Nilsson, H.; Pålsson, J. Improving the coexistence of offshore wind farms and shipping: An international comparison of navigational risk assessment processes. WMU J. Marit. Aff. 2018, 17, 397-434. [CrossRef]

31. Firestone, J.; Hoen, B.; Rand, J.; Elliott, D.; Hübner, G.; Pohl, J. Reconsidering barriers to wind power projects: Community engagement, developer transparency and place. J. Environ. Policy Plan. 2018, 20, 370-386. [CrossRef]

32. Polish Wind Energy Association. The Future of Offhore Wind Farms in Poland. Available online: http://psew.pl/wp-content/ uploads/2019/06/Przysz \%C5\%820\%C5\%9B\%C4\%87-morskiej-energetyki-wiatrowej-w-Polsce-raport.pdf (accessed on 4 April 2021).

33. Dalton, T.; Weir, M.; Calianos, A.; D'Aversa, N.; Livermore, J. Recreational boaters' preferences for boating trips associated with offshore wind farms in US waters. Mar. Policy 2020, 104216. [CrossRef]

34. Hooper, T.; Austen, M. The co-location of offshore windfarms and decapod fisheries in the UK: Constraints and opportunities. Mar. Policy 2014, 43, 295-300. [CrossRef]

35. Haraldsson, M.; Raoux, A.; Riera, F.; Hay, J.; Dambacher, J.M.; Niquil, N. How to model social-ecological systems?-A case study on the effects of a future offshore wind farm on the local society and ecosystem, and whether social compensation matters. Mar. Policy 2020, 119, 104031. [CrossRef]

36. Langhamer, O.; Wilhelmsson, D.; Engström, J. Artificial reef effect and fouling impacts on offshore wave power foundations and buoys-A pilot study. Estuar. Coast. Shelf Sci. 2009, 82, 426-432. [CrossRef]

37. Heffron, R.J.; McCauley, D.; Sovacool, B.K. Resolving society's energy trilemma through the Energy Justice Metric. Energy Policy 2015, 87, 168-176. [CrossRef]

38. Szejgiec-Kolenda, B.; Pardus, J.; Zaucha, J. Defining maritime space typology based on economic land-sea interaction. The case of the Polish Baltic Sea coast. Biul. Inst. Morskiego 2018, 33, 207-217. [CrossRef]

39. Statistical Office in Szczecin. Statistical Yearbook of Maritime Economy. Available online: https://szczecin.stat.gov.pl/en/ publications/statistical-yearbook/statistical-yearbook-of-maritime-economy-2020,7,17.html (accessed on 4 April 2021).

40. Ciołek, D.; Matczak, M.; Piwowarczyk, J.; Rakowski, M.; Szefler, K.; Zaucha, J. The perspective of Polish fishermen on maritime spatial planning. Ocean Coast. Manag. 2018, 166, 113-124. [CrossRef]

41. Gdansk Maritime Institute. Study of Conditions of Spatial Development of Polish Sea Areas. 2016. Available online: https: //www.msp-platform.eu/sites/default/files/study_of_conditions_of_spatial_development_0.pdf (accessed on 4 April 2021).

42. Zaucha, J. Gospodarowanie Przestrzenia Morska; Sedno, 2018. Available online: https://kromfest.cz/cumsproscomprob1976/ mcfvynlbc-185845/ (accessed on 4 April 2021).

43. Saunders, F.; Gilek, M.; Ikauniece, A.; Tafon, R.V.; Gee, K.; Zaucha, J. Theorizing social sustainability and justice in marine spatial planning: Democracy, diversity, and equity. Sustainability 2020, 12, 2560. [CrossRef]

44. Piwowarczyk, J.; Matczak, M.; Rakowski, M.; Zaucha, J. Challenges for integration of the Polish fishing sector into marine spatial planning (MSP): Do fishers and planners tell the same story? Ocean Coast. Manag. 2019, 181, 104917. [CrossRef]

45. Polish Parliament. The Act on Promoting Electricity Generation by Offshore Wind Farms. Available online: http:/ / orka.sejm.gov pl/proc9.nsf/ustawy/809_u.htm (accessed on 4 April 2021).

46. Allan, G.; Comerford, D.; Connolly, K.; McGregor, P.; Ross, A.G. The economic and environmental impacts of UK offshore wind development: The importance of local content. Energy 2020, 199, 117436. [CrossRef]

47. Nys, C.; Bailly, D. Methodology guide for semi-structured interviews. Res. Gate 2018, 20. [CrossRef]

48. Morf, A.; Moodie, J.; Gee, K.; Giacometti, A.; Kull, M.; Piwowarczyk, J.; Schiele, K.; Zaucha, J.; Kellecioglu, I.; Luttmann, A.; et al. Towards sustainability of marine governance: Challenges and enablers for stakeholder integration in transboundary marine spatial planning in the Baltic Sea. Ocean Coast. Manag. 2019. [CrossRef]

49. De Luca, E.; Nardi, C.; Giuffrida, L.G.; Krug, M.; Di Nucci, M.R. Explaining Factors Leading to Community Acceptance of Wind Energy. Results of an Expert Assessment. Energies 2020, 13, 2119. [CrossRef]

50. Feasibility Study: Establishment of an Offshore-Shuttle Executive Summary. Available online: http:/ / archive.northsearegion.eu/ files/repository/20150220180901_Summary_feasability-study_OffshoreShuttle-FINAL.pdf (accessed on 4 April 2021).

51. Concretization of the Port Concept Offshore-Häfen Nordsee SH: Logistical Solutions for Servicing and Instal-Lation of Offshore Wind Farms by Networking of Small and Medium Sized Ports. Available online: http://archive.northsearegion.eu/files/ repository/20150220180745_Summary-Brunsbuttel-Ports-report-logistical-concepts-FINAL.pdf (accessed on 4 April 2021).

52. Tafon, R.V. Small-scale fishers as allies or opponents? Unlocking looming tensions and potential exclusions in Poland's marine spatial planning. J. Environ. Policy Plan. 2019, 21, 637-648. [CrossRef] 